\title{
Epidemiology and control of hepatitis B infection: a perspective from the Philippines, Asia
}

\author{
M A D Lansang
}

\begin{abstract}
The prevalence of chronic hepatitis $B$ virus (HBV) infection in the Philippines, as indicated by hepatitis $B$ surface antigen (HBsAg) positivity, ranges from $2 \%$ to $16.5 \%$, with an average of $12 \%$ in a study of rural villagers. Although mother to child transmission is a major route of $\mathrm{HBV}$ infection, other routes (particularly child to child transmission) play an important part after the first year of life. In a study assessing the feasibility and effectiveness of incorporating hepatitis $B$ vaccine into the national Expanded Programme on Immunisation, the coverage rate for fully immunised 1 year olds ranged from 80.9-84\% and anti-HBs seroconversion rates ranged from $72-88 \%$. In countries where HBV is not endemic, high risk groups include commercial sex workers (CSWs) and intravenous drug users (IVDUs), who generally have higher HBsAg positivity rates than the general population. In countries with a high $\mathrm{HBV}$ endemicity, carrier rates may be only slightly higher among CSWs, suggesting that other modes of transmission are more important in those regions. CSWs who are also IVDUs are at even greater risk. If $\mathrm{HBV}$ infection is to be controlled, innovative education and screening programmes are needed, together with the mass immunisation of neonates now started in many countries around the world.
\end{abstract}

(Gut 1996; 38 (suppl 2): S43-S47)

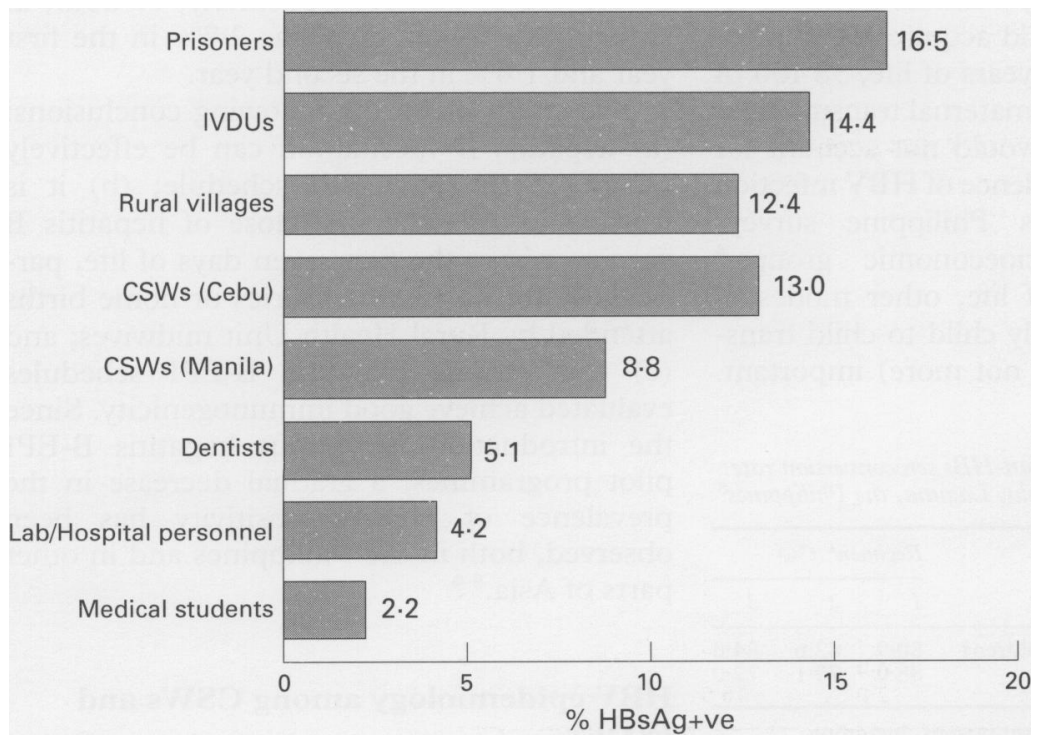

$H B s A g$ positivity rates in various surveys in the Philippines ${ }^{2-5}$ (and EB Dy, unpublished data).
Keywords: hepatitis B, transmission, control, immunisation, commercial sex workers, intravenous drug use.

Hepatitis $\mathrm{B}$ virus (HBV) infection is a major public health problem in the Philippines. The impact of this infection is primarily on the considerable number of disability adjusted life years lost from the chronic sequelae of HBV infection. These include chronic hepatitis, cirrhosis, and hepatocellular carcinoma (HCC), the last of these ranking as one of the leading causes of cancer deaths among Filipino males. A case control study of HCC conducted by Lingao et al showed that the odds ratio for HCC among hepatitis B surface antigen (HBsAg) positive Filipinos was 11.07 (95\% CI 4.88 to $25 \cdot 30$ ), with the crude odds being slightly higher among men than women. ${ }^{1}$ The first part of this paper will review the epidemiology of $\mathrm{HBV}$ infection in the Philippines, including the major modes of transmission and intervention measures for control in the country. The second part of the paper will focus on the epidemiology of HBV infection among commercial sex workers (CSWs) and intravenous drugs users (IVDUs). These two risk groups are currently not the major focus of interventions in developing countries like the Philippines, but they none the less warrant attention in both HBV endemic and non-endemic countries if better control and, eventually, eradication are to be achieved. Recommendations for control in the Philippines and for these two risk groups are also made.

\section{HBV epidemiology in the Philippines}

PREVALENCE

The Figure shows the prevalence of HBsAg positivity among various groups that have been surveyed in the Philippines. The prevalence ranges from a relatively low rate of $2 \%$ among medical students who have not yet been exposed to direct patient care, to a high of $16.5 \%$ among prisoners $^{2-5}$ (and EB Dy, unpublished data). In a survey of four villages in different provinces of the Philippines, the HBsAg prevalence ranged from $9-15 \%$, with an average rate of $12 \%$. These rural villagers generally belonged to the lower socioeconomic class. ${ }^{4}$ Some variability in the age specific rates was observed between the four villages, but two distinct patterns emerged: in two villages, an early peak in HBsAg rates occurred at around 5 years of age, while, in the other two villages, there was a late peak in HBsAg positivity at around 35 years of age. As 
TABLE I Hepatitis B-EPI regimens evaluated in Pila, Laguna, the Philippines, 1988-1990 $(n=1680)^{8}$

\begin{tabular}{|c|c|c|c|c|}
\hline $\begin{array}{l}\text { Vaccine } \\
\text { regimens }\end{array}$ & $\begin{array}{l}\text { No of infants } \\
\text { immunised } \\
(\%)^{\star}\end{array}$ & $\begin{array}{l}\text { Hepatitis } \\
B \text { vaccine } \\
\text { dose } \\
\text { number }\end{array}$ & Schedule & $\begin{array}{l}\text { EPI } \\
\text { immunogens }\end{array}$ \\
\hline 1 & $361(21 \cdot 5 \%)$ & $\begin{array}{l}1 \\
2 \\
3 \\
4\end{array}$ & $\begin{array}{l}\text { At birth } \\
6 \text { Weeks } \\
10 \text { Weeks } \\
14 \text { Weeks } \\
9 \text { Months }\end{array}$ & $\begin{array}{l}\text { BCG } \\
\text { DPT 1, OPV1 } \\
\text { DPT } 2, \text { OPV2 } \\
\text { DPT3, OPV3 } \\
\text { Measles }\end{array}$ \\
\hline 2 & $432(25 \cdot 7 \%)$ & $\begin{array}{l}1 \\
2\end{array}$ & $\begin{array}{l}\text { At birth } \\
6 \text { Weeks } \\
10 \text { Weeks } \\
14 \text { Weeks }\end{array}$ & $\begin{array}{l}\text { BCG } \\
\text { DPT 1, OPV1 } \\
\text { DPT } 2 \text {, OPV2 } \\
\text { DPT 3, OPV3 }\end{array}$ \\
\hline 3 & $744(44 \cdot 3 \%)$ & $\begin{array}{l}1 \\
2 \\
3\end{array}$ & $\begin{array}{l}\text { At birth } \\
6 \text { Weeks } \\
10 \text { Weeks } \\
14 \text { Weeks } \\
9 \text { Months }\end{array}$ & $\begin{array}{l}\text { BCG } \\
\text { DPT1, OPV1 } \\
\text { DPT2, OPV2 } \\
\text { DPT3, OPV3 } \\
\text { Measles }\end{array}$ \\
\hline
\end{tabular}

^ 143 Infants $(8 \cdot 5 \%)$ were not given hepatitis B vaccine.

yet, there are no explanations for these differences, which would require prospective follow up studies to observe possible differences in behaviour and hygienic practices.

\section{TRANSMISSION}

The prevalence of HBsAg positivity among pregnant and puerperal Filipino women is similar to that among the general population, with a range of $5-8 \%$ in various surveys. ${ }^{267}$ The hepatitis $\mathrm{B}$ e antigen $(\mathrm{HBeAg})$ positivity rate among $\mathrm{HBsAg}$ positive women ranges from $23 \cdot 1-27 \cdot 8 \% .^{267}$ Although the prevalence of $\mathrm{HBeAg}$ positivity is lower than that found in Taiwan, the risk of infection from these infected pregnant women is, nevertheless, very high. In a cohort study carried out in the early 1980 s, looking at Filipino women who were HBsAg positive during the last trimester of pregnancy, the relative risk $(R R)$ of infection during the first two years of the child's life was 28 (95\% CI, 16.2 to 48.4 ) compared with those born to HBsAg negative mothers. ${ }^{2}$ For infants born to women who were also $\mathrm{HBeAg}$ positive, the RR was $43.6(95 \%$ CI, 25.2 to 75.6$){ }^{2}$ Extrapolating from the study data, it has been estimated that, without vaccination, 64000 children from the country's annual birth cohort of about 1.6 million would acquire $\mathrm{HBV}$ infection within the first two years of life, 38400 of which would result from maternal transmission. However, these figures would not account for $58 \%$ of the average prevalence of HBV infection estimated from various Philippine surveys among the lower socioeconomic groups. ${ }^{4}$ Beyond the first year of life, other modes of transmission - particularly child to child transmission - are equally (if not more) important.

TABLE II Coverage rate and anti-HBs seroconversion rate among neonates in a study in Pila, Laguna, the Philippines ${ }^{8}$

\begin{tabular}{llll}
\hline & \multicolumn{3}{l}{ Regimen $^{\star}(\%)$} \\
\cline { 2 - 4 } & 1 & 2 & 3 \\
\hline Coverage for fully immunised children $\dagger$ & $80 \cdot 9$ & $82 \cdot 6$ & $84 \cdot 0$ \\
Anti-HBs seroconversion rate $\neq$ & $\mathbf{8 8 . 0}$ & $79 \cdot 1$ & $\mathbf{7 2 \cdot 0}$
\end{tabular}

See Table I. †All doses of all immunogens, including hepatitis $B$ vaccine, received by 1 year of age. $\neq p<0.001$ regimen 1 versus $3 ; p=0 \cdot 06$, regimen 2 versus 3 (by logistic regression analysis)
IMMUNISATION FEASIBILITY STUDIES

In an area such as the Philippines, with high HBV endemicity, universal immunisation of newborn infants, rather than selective immunisation of infants born to $\mathrm{HBsAg}$ positive mothers, is the key to control of HBV infection. In 1988, we embarked on a study in the town of Pila, Laguna, the Philippines, to evaluate the feasibility and effectiveness of incorporating hepatitis B vaccine into the Expanded Programme on Immunisation (EPI) ${ }^{8}$ Within the context of this research, we also attempted to evaluate a variety of hepatitis $B$ vaccine regimens within the EPI schedule.

Table I shows the different hepatitis B vaccine regimens used, together with the EPI vaccines of the Philippines Department of Health. Newborn infants were randomly assigned to receive either regimen 1 or regimen 2 during the first year of the study. During the second year, only regimen 3 was used. The hepatitis $B$ vaccine used was a heat inactivated, plasma derived vaccine given intramuscularly at $1.5 \mu \mathrm{g} / \mathrm{kg} /$ dose $(0.5 \mathrm{ml} /$ dose $)$. The infants were followed up by the research team at six and 12 months, and, whenever possible, at 24 months. Antibody to HBsAg (anti-HBs), antibody to the core antigen (anti-HBc), and HBsAg were determined by radioimmunoassay.

Using a delivery system provided entirely by staff of the Rural Health Unit in the study area, the coverage rate for fully immunised children ranged from $80.9 \%$ to $84 \%$ (Table II). ${ }^{8}$ In both bivariate and multivariable analyses, the type of hepatitis B vaccine schedule significantly influenced the anti-HBs response of the immunised infants. The highest anti-HBs seroconversion rate was reported for regimen 1 $(88 \%)$ and the lowest for regimen $3(72 \%)$ (Table II). Neither timeliness of administration of hepatitis $B$ vaccines nor storage conditions (intact cold chain versus short storage at room temperature) were found to have a significant effect on the anti-HBs response. In addition, only six $(0.48 \%)$ of the infants followed up were found to be HBsAg positive. The overall infection rate, as reflected by HBsAg or anti-HBc positivity, or both, in six monthly follow ups, was $2 \cdot 7 \%$ in the first year and $1.6 \%$ in the second year.

The study led to the following conclusions: (a) hepatitis B vaccination can be effectively integrated into the EPI schedule; (b) it is feasible to give the first dose of hepatitis B vaccine within the first seven days of life, particularly for hospital deliveries or home births attended by Rural Health Unit midwives; and (c) the various hepatitis B-EPI schedules evaluated achieve good immunogenicity. Since the introduction of various hepatitis B-EPI pilot programmes, a gradual decrease in the prevalence of HBsAg positivity has been observed, both in the Philippines and in other parts of Asia. ${ }^{89}$

\section{HBV epidemiology among CSWs and IVDUs}

Although mother to child transmission and child to child transmission are the most 
TABLE III Prevalence of HBV infection among CSWs compared, where data are available, to general population or control groups in various countries $513-23$

\begin{tabular}{|c|c|c|c|c|}
\hline Country ${ }^{\text {ref }}$ & $\begin{array}{l}\% C S W s \\
H B s A g+v e\end{array}$ & $\begin{array}{l}\% C S W s \text { with } \\
\text { HBV exposure }\end{array}$ & $\begin{array}{l}\% G e n / C G \\
H B s A g+v e\end{array}$ & $\begin{array}{l}\% \text { Gen/CG with } \\
\text { HBV exposure }\end{array}$ \\
\hline $\begin{array}{l}\text { Endemic count } \\
\text { China }^{13} \\
\text { Taiwan }^{14} \\
\text { Philippines }^{5} \\
\text { Singapore }^{15} \\
\text { Malaysia }^{16}\end{array}$ & $\begin{array}{l}\text { Asia } \\
21 \cdot 6 \\
16 \cdot 7-19 \cdot 6 \\
8 \cdot 8-13 \cdot 0 \\
9 \cdot 7 \\
9 \cdot 1\end{array}$ & $\begin{array}{l}84 \cdot 8 \\
- \\
58 \cdot 3 \\
71 \cdot 0 \\
76 \cdot 3\end{array}$ & $\begin{array}{l}\text { NA } \\
15-20 \text { (Gen) } \\
12 \text { (Gen) } \\
4.3 \text { (Gen) } \\
6 \cdot 8 \text { (CG) }\end{array}$ & $\begin{array}{l}\text { NA } \\
\text { NA } \\
\text { NA } \\
\text { NA } \\
\text { NA }\end{array}$ \\
\hline $\begin{array}{l}\text { Other countries } \\
\text { Japan } \\
\text { Spain }^{18} \\
\text { Peru }^{19} \\
\text { USA }^{2021} \\
\text { Australia }^{22} \\
\text { Mexico }^{23}\end{array}$ & $\begin{array}{l}7 \cdot 2 \\
4 \cdot 6 \\
1 \cdot 7 \\
- \\
\overline{0} \cdot 8\end{array}$ & $\begin{array}{l}-\overline{31} \cdot 2 \\
67 \cdot 0 \\
56-80 \\
14-58 \\
8 \cdot 2\end{array}$ & $\begin{array}{l}\text { NA } \\
1.0(C G) \\
0 \cdot 8(C G) \\
\text { NA } \\
\text { NA } \\
0.8(C G)\end{array}$ & $\begin{array}{l}\text { NA } \\
\text { NA } \\
\text { NA } \\
6 \text { (Gen) } \\
5 \text { (Gen) } \\
2 \cdot 2 \text { (CG) }\end{array}$ \\
\hline
\end{tabular}

Gen: general population; CG: control group; NA: not available.

common routes of infection in HBV endemic countries, other groups at high risk, especially among adults, are CSWs and IVDUs. In developed countries where $\mathrm{HBV}$ infection is not endemic, sexual activity is the most important risk factor. ${ }^{10}$ Among HBsAg positive adults, the presence of HBsAg has been demonstrated in around half of all sperm samples, in most vaginal secretions, in menstrual blood, and in oral secretions. ${ }^{11} 12$ During sexual intercourse, breaks in the mucous membranes and skin can facilitate the transmission of $\mathrm{HBV}$.

PREVALENCE AMONG CSWS

Table III shows the prevalence of HBsAg among CSWs in various endemic and nonendemic countries and, where available, rates among the general population or control groups. ${ }^{5}{ }^{13-23}$ In this review, the highest HBV infection rates in Asia were found in Taiwan and in detention houses in Guangzhou and Fuzhou in China. ${ }^{13} 14$ In some countries, such as China and Singapore, the prevalence of $\mathrm{HBsAg}$ positivity was higher among CSWs than among the general population. In Singapore, for example, the HBsAg positivity rate among CSWs was found to be $9 \cdot 7 \%$, compared with $4.3 \%$ in the general population. ${ }^{15}$ In countries like Taiwan, the Philippines, and Malaysia, the HBsAg carrier rates among CSWs were only slightly higher or equivalent to those found in the general population, suggesting that other modes of transmission are far more important in these countries. In Malaysia, although the $\mathrm{HBsAg}$ positivity rate for CSWs was not significantly different from that of controls $(9.1 \%$ and $6.8 \%$, respectively), the anti-HBc positivity rate was significantly higher in the former compared with the latter $\left(67 \cdot 2 \%\right.$ and $38 \cdot 9 \%$, respectively). ${ }^{16}$ These findings would be compatible with HBV

TABLE IV Prevalence of HBV infection among IVDUs compared, where data are available, to the general population in various countries $515212428-3335$

\begin{tabular}{lclll}
\hline Country & $\begin{array}{l}\text { ref } \\
\text { HBs AVUs }\end{array}$ & $\begin{array}{l}\text { \% IVDUs with } \\
\text { HBV exposure }\end{array}$ & $\begin{array}{l}\% \text { Gen } \\
\text { HBsAg+ve }\end{array}$ & $\begin{array}{l}\text { \% Gen with } \\
\text { HBV exposure }\end{array}$ \\
\hline Philippines $^{5}$ & $14 \cdot 4$ & $82 \cdot 7$ & $1 \cdot 2$ & NA \\
Singapore $^{1528}$ & $8 \cdot 0$ & $62 \cdot 0$ & $4 \cdot 3$ & NA \\
Italy $^{29}$ & $7 \cdot 4$ & $61 \cdot 4$ & NA & NA \\
Other European countries $^{30-32}$ & - & $68-78$ & NA & NA \\
USA $^{2133}$ & - & $71 \cdot 0$ & NA & 6 \\
Australia $^{2435}$ & - & $42 \cdot 0$ & NA & 5
\end{tabular}

Abbreviations as Table III. infection occurring later in life - perhaps during work as an adult CSW - when the probability of progressing to chronic HBsAg carriage is lower than that following infection during infancy and childhood.

CSWs in the 'other countries' shown in Table III generally had a lower prevalence of HBsAg positivity and HBV exposure compared with those from endemic countries in Asia. In Japan, Peru, and Mexico, there were no statistically significant differences in $\mathrm{HBsAg}$ positivity rates between CSWs and controls. However, the prevalence of other $\mathrm{HBV}$ markers was significantly higher in CSWs than in controls, ${ }^{171923}$ a pattern similar to that seen in Malaysia. In non-endemic countries like Spain, the USA, and Australia, the prevalence of $\mathrm{HBV}$ infection was substantially higher in CSWs than in the general population. ${ }^{18} 20-22$

\section{RISK FACTORS AMONG CSWS}

Rick factors that have been significantly associated with HBV transmission among CSWs are as follows: intravenous drug use, sexually transmitted diseases (particularly syphilis and human immunodeficiency virus-1 (HIV-1) infection), number of sexual partners, sexual contact with persons at high risk of $\mathrm{HBV}$, and certain racial or ethnic groups. ${ }^{1618} 21-25$ No consistent associations have been shown between hepatitis $\mathrm{B}$ seropositivity and other risk factors, such as number of years as a CSW, age, anal intercourse, and condom use. ${ }^{19} 20242627$

\section{PREVALENCE AMONG IVDUS}

The risks associated with intravenous drug use, whether or not the subjects are CSWs, are especially high. Table IV lists the prevalence of HBV infection among IVDUs in different countries. $515212428-3335$ In endemic countries in Asia, the prevalence of HBV markers among IVDUs was higher than that in the general population. Interviews with IVDUs in the Philippines showed that single use of 'disposable' syringes was almost unheard of and that injecting paraphernalia were generally cleaned only with alcohol or soap and water. ${ }^{5}$ In nonendemic countries, although rates for $\mathrm{HBV}$ exposure among IVDUs were higher than the general population, they were similar to those found in CSWs. As noted earlier, however, CSWs who were also injecting drug users were twice as likely to be infected with $\mathrm{HBV}$ as non-injecting CSWs. ${ }^{21}$ Aside from sexual transmission of $\mathrm{HBV}$, the concomitant use of intravenous drugs among CSWs may partly account for similar HBV infection rates found in these two risk groups in non-endemic countries.

RISK FACTORS AMONG IVDUS

Risk factors that have been associated with HBV markers positivity among IVDUs are as follows: HIV seromarker positivity, number of drug injecting sexual partners, number of sexual partners, and duration of intravenous drug use. ${ }^{31} 32$ 


\section{COINFECTION WITH HBV AND HCV}

As with HIV-1, some of the risk factors associated with hepatitis $\mathrm{C}$ virus (HCV) infection are the same as those for HBV infection, particularly intravenous drug use. Both IVDUs and CSWs, therefore, should also be investigated for markers of $\mathrm{HCV}$ infection. ${ }^{30} 34$ In developed countries, coinfection with $\mathrm{HBV}$ and $\mathrm{HCV}$ among IVDUs and CSWs is common, while coinfection rates in developing countries can vary considerably. In a survey of Filipino IVDUs, $60.6 \%$ were found to be positive for both anti-HCV and anti-HBc, and $9 \cdot 6 \%$ were positive for anti-HCV, anti-HBc, and HBsAg. ${ }^{5}$ Among Filipino CSWs surveyed, however, concomitant anti-HCV and anti-HBc positivity was seen in only $6 \%$, and only one of 216 CSWs was also positive for HBsAg. ${ }^{5}$ This suggests that $\mathrm{HBV}$ is more efficiently transmitted through sexual contact than $\mathrm{HCV}$, but that the parenteral route is an important mechanism for both viruses.

\section{Control of HBV infection}

\section{EDUCATION AND SCREENING}

For CSWs and IVDUs, innovative health education and counselling strategies are needed to convey important messages pertaining to safe sex practices, including the use of barrier contraceptives and possible health risks of extravaginal intercourse, and the use and risks of needles and syringes. Drug treatment programmes, including needle exchange schemes have been used with a degree of success in some countries like Australia, ${ }^{22}$ but have not been uniformly successful elsewhere. ${ }^{30}$ Screening for sexually transmitted diseases in high risk populations could also help to reduce the incidence of $\mathrm{HBV}$ infection in these groups.

Screening for HBV markers, followed by vaccination of seronegative high risk people, has been attempted, again with varying degrees of success. ${ }^{2230}$ Ensuring compliance with screening programmes and adherence to a complete course of vaccination in these risk groups may be difficult. Universal immunisation during infancy would eventually obviate problems of coverage in older age groups and among comparatively inaccessible risk groups.

\section{IMMUNISATION}

Over 75 countries have adopted a national policy of immunising all infants with hepatitis $B$ vaccine, most of which are in Eastern and Southeast Asia, the Pacific Basin, and the Middle East. ${ }^{36}$ In the Philippines, the government's Department of Health launched a three pronged HBV control programme in 1989, entailing mass immunisation of infants, screening of blood and blood products, and health education and public information. Because of limited resources, the immunisation programme commenced with a target of $40 \%$ of infants born each year, increasing every year by another $10 \%$ or more, depending on available resources.

\section{Conclusions}

The partial implementation of the 'mass' immunisation programme in the Philippines cannot be expected to reduce the burden of infection as impressively and rapidly as in countries like Taiwan and the Gambia, since transmission from unvaccinated infected children will probably persist. If the cost of hepatitis $B$ vaccine matched that of the other immunogens in the EPI, comprehensive control would be more feasible for poorer countries. The control programme would cover, in order of priority: immunisation of newborn infants, an effective blood safety programme, use of disposable needles and syringes, continuing health education of the public (particularly high risk groups), 'catch up' immunisation of older children and other risk groups, and development of secondary prevention strategies for chronically infected people. For these to be achieved, effective partnerships are needed between the public and private sectors participating in hepatitis B control.

1 Lingao AL, Domingo EO, Nishioka K. Hepatitis B virus profile of hepatocellular in the Philippines. Cancer 1981; 48: $1590-5$.

2 Domingo EO, Lingao AL, Lansang MA, Gonzales GG, West SK. Hepatitis B infection in the Philippines: epidemiology and prospects for control. In: Hepatitis B virus infections: current status and recent developments. Asean infections: current status and recent deve

3 Basaca-Sevilla V, Cross JH, Pastrana E. The hepatitis B problem in the Philippines. Southeast Asian $\mathcal{F}$ Trop Med Publ Health 1986; 17: 75-81.

4 Lingao AL, Domingo EO, West S, et al. Seroepidemiology of hepatitis B virus in the Philippines. Am $\mathcal{F}$ Epidemiol 1986; 123: 473-80.

5 Domingo EO, Lansang MA, Montejo $\mathrm{M}$, et al. Seroepidemiology of hepatitis C infection in the Philippines. Technical report to the Philippine Council for Health Research and Development, 1995.

6 Lansang MA, Domingo EO, Lingao AL, West SK, Alisago E. Sensitivity and specificity of capillary blood $\mathrm{HBsAg}$ as a surrogate marker for $\mathrm{HBeAg}$ in pregnant women. $\mathcal{f}$ surrogate marker for HBeAg in pr
Gastroenterol Hepatol 1987; 2: 159-65.

7 Sy NE, Basaca-Sevilla V, Esguerra T, Beasley RP, Hwang $\mathrm{LY}$, Cross JH. HBsAg and $\mathrm{HBeAg}$ markers among pregnant women in Manila, Philippines. Trans Roy Soc Trop Med Hyg 1986; 80: 767-70.

8 Lansang MA, Domingo EO, Miguel C, Aligui G, Alagon D, Dayrit E. Integrating hepatitis $\mathrm{B}$ immunization into the Expanded Program of Immunization. $7 A M A$, Southeast Asia 1994; (Dec suppl): 139-42.

9 Gust ID. Integration of HB vaccine into EPI in Indonesia the role of the International Task Force on Hepatitis B immunization. Proceedings of the VIIIth biennial scientific meeting, Asian-Pacific Association for the Study of the Liver. meeting, Asian-Pacific Association for the Sima
Seoul, Korea, April 6-8, 1992; 1: 45-57.

10 Alter MJ. Heterosexual activity: A leading risk factor in the transmission of hepatitis B. In: Piot P, Andre FE, eds Hepatitis B: a sexually transmitted disease in heterosexuals. Amsterdam: Elsevier Science, 1990: 17-22.

11 Plot P, Vandenbruaene M, Kegels E, Goilav C. Heterosexual transmission of hepatitis $B$ virus. In: Plot $P$, Andres FE, eds. Hepatitis B: a sexually transmitted disease in heterosexuals. Amsterdam: Elsevier Science, 1990: 81-5.

12 Pollock JJ, Andors L, Gulumoglu, Ells PF. Direct measurement of hepatitis B viral antibody and antigen markers in ment 1984; 57: 499-503.

13 Wu Q, Li Y, Fan J. A seroepidemiological study on sexually transmitted HBV infection [English abstract]. Chung Hua transmitted HBV infection [English abstract]. Ch
Liu Hsing Ping Tsueh Tsa Chih 1994; 15: 67-70.

14 Chen CJ, Hwang SJ, Fan KY, et al. Seroepidemiology of human $\mathrm{T}$ lymphotropic viruses and hepatitis viruses among prostitutes in Taiwan. $\mathcal{F}$ Infect Dis 1988; 158: 633-5.

15 Goh CL, Kamarudin A, Chan SH, Rajan VS. Hepatitis B infection markers in prostitutes in Singapore. Genitourin Med 1985; 61: 127-9.

16 Gan CY, Yap SF, Ngeow YF, Wong HC. Hepatitis B infection among Chinese STD patients in Kuala Lumpur, Malaysia. Sex Transm Dis 1991; 18: 84-8.

17 Nakashima K, Kashiwagi S, Noguchi A, et al. An epidemiological study of HBV and HTLV-1 among high risk groups in Fukuoka City [English abstract]. Kansenshogaku Zasshi 1990; 64: 419-24.

18 Bratos MA, Eiros JM, Orduña A, et al. Influence of syphilis in hepatitis B transmission in a cohort of female prostiin hepatitis B transmission in a cohort

19 Hyams KC, Phillips IA, Tejada A, et al. Hepatitis B in a highly active prostitute population: evidence for a low risk of chronic antigenemia. F Infect Dis 1990; 162: 295-8. 
20 Elifson KW, Boles J, Sweat M. Risk factors associated with HIV infection among male prostitutes. Am $\mathcal{f}$ Publ Health 1993; 83: 79-83.

21 Rosenblum L, Darrow W, Witte J, et al. Sexual practices in the transmission of hepatitis $B$ virus and prevalence of hepatitis delta virus infection in female prostitutes in the United States. $¥ A M A$ 1992; 267: 2477-81.

22 Anderson B, Bodsworth NJ, Rohrsheim R, Donovan BJ. Hepatitis $B$ virus infection and vaccination status of high risk people in Sydney: 1982 and 1991. Med 7 Australia 1994; 161: 368-71.

23 Hyams KC, Escamilla J, Lozada-Romero R, MacarenoAlvarado E. Hepatitis $B$ infection in a non-drug abusing prostitute population in Mexico. Scand f Infect Dis 1990; prostitute popu $527-31$.

24 Tabet SR, Palmer DL, Wiese WH, Voorhees RE, Pathak DR. Seroprevalence of HIV-1 and hepatitis B and C in prostitutes in Albuquerque, New Mexico. Am $\mathcal{F}$ Public Health 1992; 82: 1151-4.

25 Wang EE, King S, Goldberg E, Back B, Nfilner R, Read S Hepatitis $B$ and human immunodeficiency virus infection in street youths in Toronto, Canada. Pediatr Infect Dis $\mathcal{F}$ 1991; 10: 130-3.

26 Orduna A, Bratos MA, Gutierrez P, et al. Infection by hepatitis $B$ and $C$ virus in non-intravenous drug using female tis $B$ and $C$ virus in non-intravenous drug using

27 Goh CL, Rajan VS, Chan SH, Kamarudin A. Hepatitis B infection in prostitutes. Int $\mathcal{F}$ Epidemiol 1986; 15: 112-5. 28 Goh KT. Epidemiology and control of hepatitis $B$ virus infection Information Center/International Medical Foundation of Japan, 1992
29 Coppola RC, Manconi PE, Prio R, Di Martino ML, Masia G. HCV, HIV, HBV and HDV infections in intravenous drug addicts. Eur $\mathcal{f}$ Epidemiol 1994; 10: 279-83.

30 Van Ameijden EJC, Van den Hoek JAR, Mientjes GHC Coutinho RA. A longitudinal study on the incidence and transmission patterns of HIV, HBV and $\mathrm{HCV}$ infection among drug users in Amsterdam. Eur f Epidemiol 1993; 9: 255-62.

31 Torrella-Ramos A, Hernandez-Aguado I, Santos-Rubio C, Fernandez-Garcia E, Garcia de la Hera M, Avino-Rico MJ. Determinants of the prevalence of hepatitis B viral infection in parenteral drug abusers [English abstract]. Rev Clin Esp 1993; 193: 475-9.

32 Struve J, Kall K, Stendahl P, Scalia-Tomba G, Giesecke J, Weiland $O$. Prevalence of hepatitis $B$ virus markers among intravenous drug abusers in Stockholm: impact of heterosexual transmission. Scand $f$ Infect Dis 1993; 25: $8-13$.

33 Zeldis JB, Jain S, Kuramoto IK Infect Dis 1993; 25: 8-13. viral infections among intraens drug users in Northern California. West f Med 1992; 156: 30-5.

34 Maayan S, Shufman EN, Engelhard D, Shouval D. Exposure to hepatitis B and C and to HTLV-1 and 2 among Israeli drug abusers in Jerusalem. Addiction 1994; 89: 869-74.

35 Christopher PJ, Mailler PT, Creve EB, Murphy AM. Hepatitis B infection among STD clinic patients in Hepatitis B infection among STD clinic
Sydney. Aust NZ ₹ Med 1984; 14: 491-4.

36 Kane MA. Hepatitis B control through immunization. Subcommittee meetings of the Scientific Advisory Group of Experts (SAGE), Global Programme for Vaccines and Immunization, World Health Organization. Geneva, Switzerland, 12-16 June 1995. 